\title{
REVIEW
}

\section{Reimund Bieringer and Didier Pollefeyt, Eds. \\ Paul and Judaism: Crosscurrents in Pauline Exegesis and the Study of Jewish-Christian Relations}

\author{
(London-New York: T \& T Clark, 2012), hardcover, xiv + 256 pp. \\ Thomas D. Stegman, S.J., Boston College
}

This volume consists of revised and edited papers given at an international conference, "New Perspectives on Paul and the Jews," held in Leuven on September 14-15, 2009. The conference sought to "bring together different perspectives and approaches from the areas of biblical exegesis and Jewish-Christian dialogue" (p. xiii). Accordingly, the book contains five essays that offer an exegetical perspective and four essays that discuss Paul and contemporary Jewish-Christian dialogue. The exegetical essays include: Michael F. Bird's "Salvation in Paul's Judaism?"; William S. Campbell's "Covenantal Theology and Participation in Christ: Pauline Perspectives on Transformation"; Thomas R. Blanton IV's "Paul's Covenantal Theology in 2 Corinthians 2.147.4"; Michael Bachmann's "Paul, Israel and the Gentiles: Hermeneutical and Exegetical Notes"; and Mark D. Nanos's "Paul's Relationship to Torah in Light of his Strategy 'to Become Everything to Everyone' (1 Corinthians 9.19-23)." The dialogical essays include: Philip A. Cunningham's "Paul's Letters and the Relationship between the People of Israel and the Church Today"; John T. Pawlikowski's "A Christian-Jewish Dialogical Model in Light of New Research on Paul's Relationship with Judaism"; Hans-Joachim Sander's "Sharing God with Others or Dividing God from Powerlessness: A Late-Modern Challenge by the Heterotopian Experience of the New Paul"; and Hans Hermann Henrix's "Paul at the Intersection between Continuity and Discontinuity: On Paul's Place in Early Judaism and Christianity as well as in Christian-Jewish Dialogue Today." In addition, the two editors authored "Prologue: Wrestling with the Jewish Paul," and James D. G. Dunn (who was unable to attend the conference) wrote an epilogue. The prologue and epilogue function as the loci where the two perspectives or approaches are brought into dialogue.

As Bieringer and Pollefeyt point out in the prologue, the essays as a whole home in on two fundamental points: 1) the historical question of continuity or discontinuity regarding Paul's relationship with Judaism; and 2) the soteriological question of whether Paul espoused an understanding of salvation as inclusive, exclusive, or pluralist (this question is closely linked to the theological debate about covenant theories). In line with the insights produced by the "New Perspective on Paul," the majority of essays tend toward historical continuity and soteriological inclusivism. In this regard, Bird's essay stands out as a notable exception. He contends that "Paul conceived of Christ-believers as a...third race" (p. 29), and concludes by stating that "for Paul, salvation is of Judaism only in so far as Judaism is of Jesus Christ" (p. 40).

I want to highlight two of the exegetical essays. Bachmann makes a rigorous case for interpreting the phrase "Israel of God" in Gal 6:16-in line with Paul's consistent usage elsewhere-as referring to "real Judaism," that is, only to Jews (both non-Christian Jews and Christian Jews). In this reading, Paul concludes the contentious letter to the Galatians by praying for peace and mercy not only for those in Christ but also for "the Israel of God." Thus, according to Bachmann, 
"a disinheritance or expropriation of Judaism does not (yet) take place" (p. 104). He links Gal 6:16 with Rom 11:26-27, where Paul famously asserts "all Israel will be saved."

Nanos_the only Jewish scholar in this volume-makes an intriguing argument for rendering Paul's statement about becoming all things to all people as referring not to lifestyle adaptability but to "rhetorical adaptability" (p. 124). In other words, what Paul claims to do here is to begin with the premises and concepts of his interlocutors and from there to attempt to persuade them to accept his convictions about the gospel. Nanos supports his argument with the presentation of Paul in Acts 17 and with Antisthenes's interpretation of Odysseus as a "polytrope" (p. 134). It should be noted that Nanos holds that Paul continued to keep faithfully Torah after his encounter with Christ. Dunn, in his epilogue, rightly chides Nanos for not reckoning with 1 Cor 7:19, where Paul suggests that "he thought that some commandments of the Torah no longer mattered, while still being committed to observing the commandments of God" (p. 216). Nevertheless, Nanos's interpretation of the claim that Paul employed "rhetorical adaptability" deserves careful consideration vis-à-vis Paul's evangelistic tactic. I also appreciated the way both Bachmann and Nanos concluded their exegetical analyses with thoughtful suggestions for the relevance of Paul's thought for Jewish-Christian relations.

Of the dialogic essays, Cunningham's stands out. Employing the biblical hermeneutic of Sandra M. Schneiders (see The Revelatory Text: Interpreting the New Testament as Sacred Scripture [2 $2^{\text {nd }}$ ed; Collegeville, MN: The Liturgical Press, 1999]), Cunningham sets forth an engagement between exegesis / explanation (what the text meant) and contemporary concerns (what the text can mean). In particular, he addresses how Paul's teaching in Romans 11 can be actualized in "a post-Shoah, post-Nostra Aetate Church" (p. 153).

One can cull out from this volume a number of constructive proposals in connection with the study of Paul and its relevance for Jewish-Christian relations. Cunningham lists six important implications of his analysis (pp. 153-161), including an appropriation of Paul's caution to the Gentiles in the churches in Rome that they have no ground for boasting, and of his exhortation that they be holy and loving so that others can approach them with trust and without fear. Sander sets forth some challenging implications for taking seriously the Pauline emphasis on the paradox of power working through weakness. Henrix proposes that life-giving actualization of Scripture means that one should "criticize the Scriptures by means of the Scriptures" (p. 193). Bieringer and Pollefeyt point out that Paul's vision is ultimately theocentric (1 Cor 15:28), rather than Christocentric or pneumatocentric. They also suggest a hermeneutical approach called "the Normativity of the Future," a dialogical approach that "puts an emphasis on the contemporary reading community and their ability, through engaging with the Spirit who transcends the text, to go beyond the limitations of the biblical text and 'write their own fifth gospel'" (p. 13).

There is much to commend about this volume. One significant deficit is the lack of interaction among the participants in their edited papers. (Only Sander does this, in addition to the prologue and epilogue.) To be sure, the subtitle makes clear that the contents are "crosscurrents." Nevertheless, it would have improved the work to have more interaction between the essays and to have more "controls" on terminology. As Dunn justly criticizes, the term "Judaism" is employed throughout the volume with varying referents. 